\title{
A SUGGESTION TO EASE THE BURDEN OF
}

\author{
PROFESSIONAL UAEMPLOYMENT
}

Frofessor Mary B. Williams

\section{Purpose:}

The academic community has a responsibility to do what it can to help the research-oriented $\mathrm{Ph} . \mathrm{D}$.' $\mathrm{B}$ who are suffering a period of professional unemployment because of the present academic job crisis. The purpose of the following suggestion is to help these scholars get the professional feedback which is important in maintaining the ability to do good research.

\section{Suggestion:}

Professionally unemployed $\mathrm{Ph} . \mathrm{D}$. 's who wish to maintain active ties to the academic community should be encouraged to apply for an appointment as Adjunct Professor to an educational institution in the city in which they live. Adjunct Professor would be an unsalaried position with library privileges but no departmental duties. Since it is important that the Ad junct Professor be accepted as the professional equal of his departmental colleagues (rather than as a second class citizen), his application should contain the same supporting information as an application for a regular positions and it should be rejected unless he appears to be of professional caliber equal to present members of the department. (It should not, however, be judged on the basis of whether he would be offered a job in that department in the present competitive situation. Thus the department would have made no commitment as to his suitability for any job that might open up in the department.) Adjunct appointments should be for a period of 3 to 5 years and should be renewed if the Adjunct Professor has maintained his standing as a research scholar.

\section{Advantages for the Adjunct Professor:}

(1) A group of professional equals with whom he could discuss his work and current work in the field. (2) An academic mailing address. (The calls for blind refereeing, and evidence that it is needed at least in some fields, indicate that this could be an important advantage.) (3) Opportunity to present his work at departmental colloquia. (4) Professional status. (5) I.ibrary privileges. 